\title{
Towards comprehension of the physiological role of UCP3
}

Citation for published version (APA):

Hesselink, M. K., \& Schrauwen, P. (2005). Towards comprehension of the physiological role of UCP3. Hormone and Metabolic Research, 37(9), 550-554. https://doi.org/10.1055/s-2005-870421

Document status and date:

Published: 01/01/2005

DOI:

10.1055/s-2005-870421

Document Version:

Publisher's PDF, also known as Version of record

Document license:

Taverne

Please check the document version of this publication:

- A submitted manuscript is the version of the article upon submission and before peer-review. There can be important differences between the submitted version and the official published version of record.

People interested in the research are advised to contact the author for the final version of the publication, or visit the DOI to the publisher's website.

- The final author version and the galley proof are versions of the publication after peer review.

- The final published version features the final layout of the paper including the volume, issue and page numbers.

Link to publication

\footnotetext{
General rights rights.

- You may freely distribute the URL identifying the publication in the public portal. please follow below link for the End User Agreement:

www.umlib.nl/taverne-license

Take down policy

If you believe that this document breaches copyright please contact us at:

repository@maastrichtuniversity.nl

providing details and we will investigate your claim.
}

Copyright and moral rights for the publications made accessible in the public portal are retained by the authors and/or other copyright owners and it is a condition of accessing publications that users recognise and abide by the legal requirements associated with these

- Users may download and print one copy of any publication from the public portal for the purpose of private study or research.

- You may not further distribute the material or use it for any profit-making activity or commercial gain

If the publication is distributed under the terms of Article $25 \mathrm{fa}$ of the Dutch Copyright Act, indicated by the "Taverne" license above, 


\section{Towards Comprehension of the Physiological Role of UCP3}

M. K. C. Hesselink ${ }^{1}$

P. Schrauwen ${ }^{2}$

\section{Abstract}

Thyroid hormones have long been known to stimulate energy expenditure partly via loss of metabolic efficiency. The mechanism underlying the loss in metabolic efficiency observed, however, is not yet understood. An important candidate gene responsible for thyroid hormone induced thermogenesis was identified in 1997 with the discovery of skeletal muscle-uncoupling protein 3 (UCP3), a protein with $\sim 60 \%$ homology to the brown adipose tissue uncoupling protein 1 (UCP1). This short review summarizes our presentation held at the 'Thyroid and Sports' meeting; it does not aim to provide a concise overview of the available literature at this topic. Although induction of the UCP3 gene and increased protein expression during hyperthyroidism has been shown, there are no convincing data that increased UCP3 levels account for the increase in thermogenesis in the hyperthyroid state in humans. In contrast to cell and animal studies using ectopic overexpression of UCP3 as a model, induction of UCP3 in humans does not result in any apparent mitochondrial uncoupling. Hence, the primary physiological role of UCP3 may not be mitochondrial uncoupling, but uncoupling may occur as a side effect of a more pivotal role played by UCP3. Recently, UCP3 has been hypothesized to export fatty acid anions and/or lipid peroxides away from the mitochondrial matrix to prevent mitochondria from the harmful effects of peroxidized lipids. The present review aims to provide an overview of studies testing the feasibility of this unconventional function of UCP3.

\section{Key words}

Skeletal muscle - Exercise - Lipotoxicity $\cdot$ Mitochondrial dysfunction · Type 2 diabetes

\section{Introduction}

Total energy expenditure in free-living organisms comprises diet-induced thermogenesis, basal metabolic rate and physical activity-induced energy expenditure. Of these three components, basal metabolic rate (BMR) usually accounts for more than $60 \%$ of total energy expenditure in homeotherms such as humans [1]. The major ( $81 \%)$ determinant of basal metabolic rate is the fat free body mass [1], which in turn mainly originates from skeletal muscle and can be measured as oxygen uptake. The vast majority of oxygen uptake is used for mitochondrial respira- tion and is coupled tot ATP synthesis. During mitochondrial respiration, a phosphor is donated to ADP at the expense of oxygen. The energy needed for phosphor donation is derived from proton pumping across the inner mitochondrial membrane (electron transport chain). If all energy built up in the electron transport chain is used to phosphorylate ADP in order to synthesize ATP, the mitochondrion is referred to as a fully coupled mitochondrion. In vivo, however, estimates of up to $20 \%$ have been made of uncoupled respiration, or energy expenditure not resulting in ATP synthesis. As uncoupled respiration is the most variable component of BMR, the discovery of UCP3 [2], a protein with ap-

Affiliation

${ }^{1}$ Department of Movement Sciences, Nutrition and Toxicology Research Institute Maastricht (NUTRIM),

Maastricht University, The Netherlands

${ }^{2}$ Department of Human Biology, Nutrition and Toxicology Research Institute Maastricht (NUTRIM)

Maastricht University, The Netherlands

Correspondence

Matthijs Hesselink, Ph. D. · Department of Movement Sciences · Maastricht University · PO Box 616 . NL-6200 MD · Maastricht · The Netherlands · Phone: +31 (43) $3881317 \cdot$ Fax: +31 (43) 3670972 .

E-Mail: matthijs.hesselink@bw.unimaas.nl

Received 22 February 2005 - Accepted after revision 22 June 2005 
proximately $60 \%$ homology to UCP1, was considered a major breakthrough in research towards the regulation of energy expenditure. Early studies on Pima Indians revealed BMR to be a very strong predictor of weight gain [3]. Interestingly, it was also shown that UCP3 mRNA levels were negatively associated with BMI and positively with BMR in Pima Indians [4]. These observations were not only made in Pima Indians but multiple conditions resulting in increased energy expenditure are paralleled by increased mRNA levels of UCP3, including prolonged cold exposure [5], endotoxemia and sepsis [6-8], suggesting that UCP3 could be related to energy expenditure. Increased energy expenditure in the hyperthyroid state was shown to occur in parallel with increased mitochondrial proton leak in liver mitochondria, with the opposite observed in hypothyroidism [9]. The combined observation of associations between increased UCP3 mRNA levels in circumstances of increased energy expenditure and thyroid-related modulation of mitochondrial proton leak has led to the hypothesis that UCP3 may be involved in thyroid-hormone induced increases in energy expenditure. The aim of this short review is to summarize our presentation held at the 'Thyroid and Sports' meeting, but does not aim to provide a concise overview of the literature available on this topic.

\section{Thyroid Hormone, UCP3, and Energy Expenditure}

Thyroid hormones have long been recognized as able to stimulate basal metabolic rate partly via loss of metabolic efficiency [9]. The routes or molecular mechanisms resulting in thyroid hormone-induced increases in energy expenditure have not yet been established. Transcriptional control of genes such as UCP3 that are putatively involved in thermogenesis may contribute to regulated stimulation of energy expenditure. Cloning of the gene encoding UCP3 resulted in the discovery of a thyroid hormoneresponsive element in the promoter region [10], indeed suggesting that UCP3 could be involved in the thermogenic response to thyroid stimulation. More recently, it has been shown that action of thyroid hormones on UCP3 gene transcription is mediated by the binding of thyroid to a proximal region in the UCP3 gene promoter [11]. Using chromatin immunoprecipitation assays, thyroid hormone was indeed shown to bind to this element in vivo [11]. The presence of response elements for thyroid hormone supports the observation that UCP3 mRNA levels in hypothyroid rats were reduced to $32 \%$ of control levels measured in euthyroidism. Administration of thyroid hormone to hypothyroid as well as to euthyroid rats resulted in 4.7 and 6.2-fold increase in UCP3 mRNA, respectively [12]. These findings were later confirmed at protein level [13] and UCP3 protein expression after a single injection peaked in parallel with an increase in BMR [14]. Hence, UCP3 may be a determinant of $\mathrm{T}_{3}$-induced changes in energy expenditure. In addition to modulation of UCP3 gene transcription by thyroid hormone, thyroid-related activation of UCP3, at least in the fasted state, has also been shown [15]. In this study, rats were fasted to induce a marked drop in Coenzyme Q levels (CoQ), previously shown to be a necessary factor in activating uncoupling proteins in general [16], and UCP3 specifically [17]. Interestingly, blunting of fasting-induced decreases in CoQ by thyroid hormone resulted in increased UCP3 mediated uncoupling [15], as indicated by its GDP and superoxide dismutase sensitivity.
Also, under other conditions, UCP3 has been associated with changes in determinants of energy expenditure; for example, UCP3 mRNA levels are inversely associated with maximal oxidative capacity and mechanical efficiency during stationary cycling [18], and mice ectopically overexpressing UCP3 are hyperphagic but lean [19]. Obviously, these associations do not imply that UCP3 is causally linked to human energy metabolism and the question remains as to whether the primary role of UCP3 is indeed mitochondrial uncoupling and regulation of energy expenditure.

\section{Is UCP3 Primarily Involved in Regulation of Energy Metabolism?}

To address this question, contraintuitive data were reported in early studies shortly after the discovery of UCP3. These studies showed induction of the UCP3 gene [20] and increased UCP3 protein content [21] after fasting. This is of interest, as fasting is considered an energy-preserving condition, while increased uncoupling would result in energy dissipation. Also, the generation of UCP3 knock-out mice does not support the idea that UCP3 primarily contributes to energy expenditure as these mice failed to have any apparent phenotype [22]. In a human model where UCP3 protein content was increased by consumption of a highfat diet, we did not observe any change in post-depletion phosphocreatine resynthesis rate, indicating that despite an almost $50 \%$ increase in UCP3 protein levels mitochondrial coupling was unaffected [23]. The failure to identify UCP3 as a bona fide uncoupling protein [24] prompted us and others to explore an alternative function of UCP3. As outlined above, UCP3 was inversely associated with maximal aerobic capacity, a marker for training status, and it seems feasible to expect a downregulation of UCP3 by exercise. Therefore, we initially examined the response of UCP3 tot acute exercise.

\section{UCP3 and Acute Exercise}

We have previously reported an inverse relation between UCP3 and oxidative capacity [18] and low UCP3 protein levels in trained individuals [25], indicating that physical exercise may affect UCP3 levels. Hence, we examined the response of UCP3 to an acute bout of exercise. The first indications that acute exercise increases rather than decreases UCP3 came from a study showing a progressive increase in transcriptional control rate of UCP3 during a four-hour recovery period after 60-90 min of exhaustive one-legged knee-extensor exercise [26]. In this respect, it is important to note that adipose tissue lipolysis is stimulated and free fatty levels steeply increase during acute exercise, especially in a fasted state. As fatty acids are recognized ligands for the transcription of many genes including UCP3 [13,27-30], it is also important to study the effect of exercise per se such that potentially confounding effects of increased fatty acids levels are taken into account, that is, under conditions with high and low fatty acid levels. To do so, we designed a study where subjects reported to the laboratory on two different occasions, once in the fasted and once in the fed state. After a pre-exercise biopsy, subjects cycled for 120 minutes followed by an additional 240 minutes of recovery with muscle biopsies taken prior to, and two and four hours after the onset of exercise. In the fasted trials, only 
plain water was provided to the subjects, whereas subjects consumed glucose drinks prior to and 60, 90, 120, 180, 240 and 300 minutes after the onset of exercise in the fed trials. The fed glucose ingestion trial almost completely abolished the rise in free fatty acids classically observed during exercise in the fasted state (FFA levels of 400 vs. $1,100 \mathrm{mmol}$, respectively) [31]. Interesting$\mathrm{ly}$, the rise in plasma FFA during the fasted trial occurred in parallel with a rise in UCP3 mRNA levels, whereas no change in UCP3 was detected in the fed state. This suggests that the acute effect of exercise on UCP3 is not accounted for by exercise itself but merely by exercise-induced changes in plasma FFA content [31], pointing towards a putative role for UCP3 in the fat metabolism.

\section{UCP3 and Fat Metabolism, the Role of Exercise Training}

A role for UCP3 in fat metabolism was also suggested by others, showing, for example, acute induction of UCP3 by lipid infusion [28]. Lipids were not only reported to affect UCP3 levels, but also lipid oxidation has been linked to UCP3; for example, a polymorphism in the promoter of the UCP3 gene was reported to result in an apparent null mutation of UCP3 [32], which was associated with decreased fat oxidative capacity as indicated by an increased respiratory quotient [32]. To test the hypothesis that UCP3 levels increase when fatty acid supply to the mitochondria exceeds fat oxidative capacity, we used models possessing either an increased or a decreased fat oxidative capacity.

Exercise training is a potent way to enhance fat oxidative capacity, resulting in increased fat oxidation measured by whole body substrate oxidation and a shift towards more fat oxidative muscle fibers. Low UCP3 protein levels were reported in a cross-sectional study in well-trained human athletes [25]. Also, UCP3 was found to be hierarchically expressed with the highest levels reported in the fast glycolytic fibers and the lowest levels in slow oxidative fibers [25]. The hierarchical expression of UCP3 was observed both in the trained and in the untrained state [25] suggesting that UCP3 increases when the fatty acid supply to mitochondria is high and fat oxidative capacity is low, and vice versa. This is supported by observations in rat cardiac muscle, an organ almost exclusively relying on fat oxidation for energy provision and well equipped to oxidize lipid, showing that UCP3 was lower than values reported for oxidative soleus muscle in the rat [33]. In a longitudinal design whereby previously untrained subjects followed an exercise-training program for three months, we observed a significant rise in fat oxidation [34] accompanied by a significant decline in UCP3 [35] that correlated with the change in triglyceride-derived fat oxidation. One short-term training study showed eleven days of exercise training within a fortnight to result in a nearly significant $(\mathrm{p}=0.08)$ decrease in UCP3 protein content [36]. Reducing fat oxidative capacity in humans for 36 hours by pharmacological intervention with carnitine-palmitoyl-transferase 1 (CPT1) inhibitor Etomoxir resulted in a significant decreased 24-hour fat oxidation and a significant increase in UCP3 protein content [37]. In situations of prolonged decrease in fat oxidation (such as mitochondrial lipid oxidation disorder riboflavin-responsive multiple acylCoAdehydrogenase deficiency (RRMAD)), impaired fat oxidation was accompanied by higher UCP3 levels than in healthy control subjects [38]. Interestingly, if RRMAD patients were treated with riboflavin, their fat oxidative capacity was restored to control values and UCP3 levels concomitantly decreased [38].

These studies, and also many others, consistently show an increase in UCP3 levels when fat oxidative capacity is low and the supply of fatty acids to the mitochondrion is maintained or elevated. The reverse also appears to be true - muscle fibers or people with a high fat oxidative capacity have low UCP3 content and any improvement in fat oxidation is accompanied by a decrease in UCP3 levels.

These findings have led us and others to suggest that the primary role of UCP3 is to lead fatty acids away from the mitochondrial matrix under conditions where fatty acid load to the mitochondria is high and fat-oxidative capacity is low $[35,39]$. Under these conditions, some of the fatty acids might not enter the mitochondrion in their esterified and oxidizable form via CPT1, but rather via flip-flop after incorporation in the inner mitochondrial phospholipid bilayer. These fatty acid anions are deprotonated due to the proton gradient across the mitochondrial membrane. As the mitochondrial matrix lacks an enzyme for esterification of long chain fatty acid anions, these fatty acid anions are stuck in the matrix and outward translocation needs a protein such as UCP3 that is capable of transporting fatty acid anions against the proton gradient in exchange for a proton, thereby reducing the proton gradient [40].

In this respect, the observation that fasting rats for 48 hours increases UCP3 content with concomitant increases in enzymes favoring fat oxidation [41] may well reflect a dual adaptive response occurring within distinct time frames. It could thus be hypothesized that the acute rise in circulatory fatty acids upon fasting may result in increased fatty acid load to the mitochondria. To relieve this load, UCP3 activity and gene transcription both acutely increase. To preserve energy, however, it is favorable to oxidize the fatty acids, explaining the increased gene transcription of fat oxidative genes. The question remains as to the physiological relevance of UCP3 as a fatty acid anion exporter.

\section{UCP3 as a Mitochondrial Fatty Acid Anion Exporter - Physiological Relevance?}

Mitochondria are the major site for production of reactive oxygen species (ROS). The abundance of ROS formation during mitochondrial respiration depends on the proton gradient across the innermitochondrial membrane such that a high proton gradient increases ROS production [42]. Fatty acid anions trapped in the mitochondrial matrix as well as intramyocellular lipids stored within vicinity of the mitochondria [43] are prone to lipid peroxidation in the presence of ROS. This reveals a dual function for UCP3:1) lowering the proton gradient to reduce ROS production and lipid peroxidation and 2) exporting the lipid peroxides formed (or fatty acid anions before they become peroxidized) away from the mitochondrial matrix. In this way, UCP3 clearly plays a role in preventing lipotoxicity and maintaining skeletal muscle mitochondrial integrity and function [44]. Support for a role of UCP3 in modulating lipotoxicity comes from in vitro assays indicating that UCP3 activity is increased by superoxide 
[17], but also by 4-hydroxy 2-nonenal (4HNE), a by-product in the metabolism of lipid peroxides [45], suggesting a negative feedback loop to control excessive ROS production and hence lipid peroxidation. In addition, mice lacking UCP3 show increased ROS production [22], increased lipid peroxidation, and damage to mitochondrial proteins [46]. These findings are in line with a physiological role of UCP3 as a mitochondrial exporter of fatty acid anions $[35,39,47]$ and/or lipid peroxides [48], rather than as an uncoupling protein per se [23].

\section{UCP3 in the Prevention of Lipotoxicity in Type 2 Diabetes}

Interestingly, a role for UCP3 in the modulation of lipotoxicity is especially apparent in type 2 diabetes. In contrast to what was anticipated (high UCP3 levels if fat oxidative capacity is low and supply of fatty acids to the mitochondrion is high, as is the case in type 2 diabetes), we observed $~ 50 \%$ lower UCP3 levels in type 2 diabetics than in healthy, BMI and age-matched controls [49]. Indeed, aberrations in mitochondrial morphology have been reported in type 2 diabetes, along with mitochondrial dysfunction $[50,51]$. It has also been shown that myocellular lipids in type 2 diabetics have increased $4 \mathrm{HNE}$ content, reflecting a higher degree of lipid peroxidation [52]. This indicates that decreased UCP3 content is part of the complex etiology of type 2 diabetes, and also that UCP3 may help prevent lipotoxicity. The combined observation of downregulation of a cluster of oxidative genes under control of PGC1 $\alpha$ in type 2 diabetes as in their first degree relatives, indicating impaired mitochondrial function $[53,54]$ and recent data from our lab reporting decreased UCP3 levels in the pre-diabetic impaired glucose tolerant state (Mensink M., submitted), suggests that decreased UCP3 levels are not only part of the etiology of type 2 diabetes, but also that low UCP3 levels contribute to the pathogenesis of type 2 diabetes. Thus, it would be important to examine what happens to UCP3 if the insulin resistant state is alleviated, either by pharmacological intervention or by other more physiological interventions.

Thiazolidinediones (TZDs), a relatively novel class of insulin sensitizers, have been shown to increase UCP3 mRNA levels in rats [55] and improve fat oxidative capacity [56], indicating improved mitochondrial function and possibly contributing to interruption of the negative feedback loop outlined above. In line with this, recent data from our lab indeed show increased UCP3 protein levels in human type 2 diabetes patients after TZD treatment. Non-pharmacological routes to improve insulin sensitivity include physical exercise training and a life style intervention comprising dietary advice and regular physical activity. In type 2 diabetes, the patients showed increased UCP3 levels (Mensink M., submitted) as did pre-diabetic impaired glucose tolerance subjects included in an exercise training program or a life-style intervention. Together, these novel observations indicate that the decrease in UCP3 is part of the pathophysiology of impaired glucose tolerance or insulin sensitivity. Note that in healthy control subjects, exercise training reduces UCP3 levels. Hence, we interpret the increase in UCP3 content in type 2 diabetes in response to TZD treatment, life-style intervention and physical exercise training as restoration of UCP3 towards control values. As such, this rise in UCP3 contributes to the restoration of mitochondrial function and prevention to lipotoxicity.

\section{Conclusion}

With the possible exception of thyroid hormone-induced UCP3mediated increases in energy expenditure, there is no compelling evidence that the primary physiological role of UCP3 is in the regulation of energy metabolism. Rather, there is an increasing amount of evidence supporting the hypothesis that UCP3 mainly serves outward translocation of fatty acid anions away from the mitochondrial matrix under conditions of a mismatch between mitochondrial fatty acid supply and fat oxidative capacity. By exporting non-oxidizable fatty acid anions in exchange for a proton, UCP3 serves to prevent lipotoxicity, not only by fatty acid anion export but also by blunting ROS production. The role of UCP3 as a fatty acid anion exporter may be of particular relevance in type 2 diabetes, where decreased UCP3 levels along with disrupted mitochondria and mitochondrial dysfunction results in a negative feed-back loop that slowly but progressively reduces mitochondrial function and hence fat oxidation. Interruption of this feed-back loop is of utmost importance in improving glucose tolerance and restoring insulin sensitivity in subjects with impaired glucose handling.

\section{References}

${ }^{1}$ Ravussin E, Lillioja S, Anderson TE, Christin L, Bogardus C. Determinants of 24-hour energy expenditure in man. Methods and results using a respiratory chamber. J Clin Invest 1986; 78: 1568-1578

2 Boss O, Samec S, Paoloni-Giacobino A, Rossier C, Dulloo A, Seydoux J et al. Uncoupling protein-3: a new member of the mitochondrial carrier family with tissue-specific expression. FEBS Lett 1997; 408: 439-442 ${ }^{3}$ Ravussin E, Lillioja S, Knowler WC, Christin L, Freymond D, Abbott WG et al. Reduced rate of energy expenditure as a risk factor for bodyweight gain. N Engl J Med 1988; 318: 467-472

${ }^{4}$ Schrauwen P, Xia J, Bogardus C, Pratley RE, Ravussin E. Skeletal muscle uncoupling protein 3 expression is a determinant of energy expenditure in Pima Indians. Diabetes 1999; 48: 146-149

${ }^{5}$ Schrauwen P, Westerterp-Plantenga MS, Kornips E, Schaart G, van Marken Lichtenbelt WD. The effect of mild cold exposure on UCP3 mRNA expression and UCP3 protein content in humans. Int J Obes Relat Metab Disord 2002; 26: 450-457

${ }^{6}$ Sun X, Wray C, Tian X, Hasselgren PO, Lu J. Expression of uncoupling protein 3 is upregulated in skeletal muscle during sepsis. Am J Physiol Endocrinol Metab 2003; 285: E512-520

${ }^{7}$ Yu XX, Barger JL, Boyer BB, Brand MD, Pan G, Adams SH. Impact of endotoxin on UCP homolog mRNA abundance, thermoregulation, and mitochondrial proton leak kinetics. Am J Physiol Endocrinol Metab 2000; 279: E433-446

${ }^{8}$ Horvath TL, Diano S, Miyamoto S, Barry S, Gatti S, Alberati D et al. Uncoupling proteins- 2 and 3 influence obesity and inflammation in transgenic mice. Int J Obes Relat Metab Disord 2003; 27: 433 - 442

${ }^{9}$ Hafner RP, Nobes CD, McGown AD, Brand MD. Altered relationship between protonmotive force and respiration rate in non-phosphorylating liver mitochondria isolated from rats of different thyroid hormone status. Eur J Biochem 1988; 178: 511 - 518

${ }^{10}$ Acin A, Rodriguez M, Rique H, Canet E, Boutin JA, Galizzi JP. Cloning and characterization of the 5' flanking region of the human uncoupling protein 3 (UCP3) gene. Biochem Biophys Res Commun 1999; 258: $278-283$

${ }^{11}$ Solanes G, Pedraza N, Calvo V, Vidal-Puig A, Lowell BB, Villarroya F. Thyroid hormones directly activate the expression of the human and mouse uncoupling protein- 3 genes through a thyroid response element in the proximal promoter region. Biochem J 2005; 386: 505-513

${ }^{12}$ Gong DW, He Y, Karas M, Reitman M. Uncoupling protein-3 is a mediator of thermogenesis regulated by thyroid hormone, beta3-adrenergic agonists, and leptin. J Biol Chem 1997; 272: 24129-24132

${ }^{13}$ Lombardi A, Silvestri E, Moreno M, De Lange P, Farina P, Goglia F et al. Skeletal muscle mitochondrial free-fatty-acid content and membrane potential sensitivity in different thyroid states: involvement of uncou- 
pling protein-3 and adenine nucleotide translocase. FEBS Lett 2002; 532: $12-16$

14 de Lange P, Lanni A, Beneduce L, Moreno M, Lombardi A, Silvestri E et al. Uncoupling protein-3 is a molecular determinant for the regulation of resting metabolic rate by thyroid hormone. Endocrinology 2001; 142: $3414-3420$

${ }^{15}$ Moreno M, Lombardi A, De Lange P, Silvestri E, Ragni M, Lanni A et al. Fasting, lipid metabolism, and triiodothyronine in rat gastrocnemius muscle: interrelated roles of uncoupling protein 3 , mitochondrial thioesterase, and coenzyme Q. Faseb J 2003; 17: 1112 - 1114

${ }^{16}$ Echtay KS, Winkler E, Klingenberg M. Coenzyme Q is an obligatory cofactor for uncoupling protein function. Nature 2000; 408: 609-613

${ }^{17}$ Echtay KS, Roussel D, St-Pierre J, Jekabsons MB, Cadenas S, Stuart JA et al. Superoxide activates mitochondrial uncoupling proteins. Nature 2002; 415: 96 - 99

${ }^{18}$ Schrauwen P, Troost FJ, Xia J, Ravussin E, Saris WH. Skeletal muscle UCP2 and UCP3 expression in trained and untrained male subjects. Int J Obes Relat Metab Disord 1999; 23: 966 - 972

${ }^{19}$ Clapham JC, Arch JR, Chapman H, Haynes A, Lister C, Moore GB et al. Mice overexpressing human uncoupling protein-3 in skeletal muscle are hyperphagic and lean. Nature 2000; 406: 415-418

${ }^{20}$ Millet L, Vidal H, Andreelli F, Larrouy D, Riou JP, Ricquier D et al. Increased uncoupling protein-2 and -3 mRNA expression during fasting in obese and lean humans. J Clin Invest 1997; 100: 2665-2670

21 Jucker BM, Ren J, Dufour S, Cao X, Previs SF, Cadman KS et al. 13C/31P NMR Assessment of Mitochondrial Energy Coupling in Skeletal Muscle of Awake Fed and Fasted Rats: Relationship with Uncoupling Protein 3 Expression. J Biol Chem 2000; 275: 39279-39286

22 Vidal-Puig AJ, Grujic D, Zhang CY, Hagen T, Boss O, Ido Y et al. Energy Metabolism in Uncoupling Protein 3 Gene Knockout Mice. J Biol Chem 2000; 275: $16258-16266$

${ }^{23}$ Hesselink MK, Greenhaff PL, Constantin-Teodosiu D, Hultman E, Saris $\mathrm{WH}$, Nieuwlaat $\mathrm{R}$ et al. Increased uncoupling protein 3 content does not affect mitochondrial function in human skeletal muscle in vivo. J Clin Invest 2003; 111: 479-486

${ }^{24}$ Nedergaard J, Cannon B. The "novel" "uncoupling" proteins UCP2 and UCP3: what do they really do? Pros and cons for suggested functions. Exp Physiol 2003; 88: 65-84

${ }^{25}$ Russell AP, Wadley G, Hesselink MKC, Schaart G, Lo S, Leger B et al. UCP3 protein expression is lower in type I, IIa and IIx muscle fiber types of endurance-trained compared to untrained subjects. Pflugers Arch 2003; 445: 563-569

${ }^{26}$ Pilegaard H, Ordway GA, Saltin B, Neufer PD. Transcriptional regulation of gene expression in human skeletal muscle during recovery from exercise. Am J Physiol Endocrinol Metab 2000; 279: E806-814

${ }^{27}$ Hwang CS, Lane MD. Up-regulation of uncoupling protein-3 by fatty acid in C2C12 myotubes. Biochem Biophys Res Commun 1999; 258: 464- 469

${ }^{28}$ Weigle DS, Selfridge LE, Schwartz MW, Seeley RJ, Cummings DE, Havel PJ et al. Elevated free fatty acids induce uncoupling protein 3 expression in muscle: a potential explanation for the effect of fasting. Diabetes 1998; 47: $298-302$

29 Jezek P. Fatty acid interaction with mitochondrial uncoupling proteins. J Bioenerg Biomembr 1999; 31: 457-466

${ }^{30}$ Samec S, Seydoux J, Dulloo AG. Skeletal muscle UCP3 and UCP2 gene expression in response to inhibition of free fatty acid flux through mitochondrial beta-oxidation. Pflugers Arch 1999; 438: 452 - 457

${ }^{31}$ Schrauwen P, Hesselink MK, Vaartjes I, Kornips E, Saris WH, Giacobino $\mathrm{JP}$ et al. Effect of acute exercise on uncoupling protein 3 is a fat metabolism-mediated effect. Am J Physiol Endocrinol Metab 2002; 282: E11 - 17

${ }^{32}$ Argyropoulos G, Brown AM, Willi SM, Zhu J, He Y, Reitman M et al. Effects of mutations in the human uncoupling protein 3 gene on the respiratory quotient and fat oxidation in severe obesity and type 2 diabetes. J Clin Invest 1998; 102: 1345 - 1351

${ }^{33}$ Hoeks J, Hesselink MK, van Bilsen M, Schaart G, van der Vusse GJ, Saris $\mathrm{WH}$ et al. Differential response of UCP3 to medium versus long chain triacylglycerols; manifestation of a functional adaptation. FEBS Lett 2003; 555: 631-637

${ }^{34}$ Schrauwen P, Wagenmakers AJ, van Marken Lichtenbelt WD, Saris WH, Westerterp KR. Increase in fat oxidation on a high-fat diet is accompanied by an increase in triglyceride-derived fatty acid oxidation. Diabetes 2000; 49: 640-646

${ }^{35}$ Schrauwen P, Saris WH, Hesselink MK. An alternative function for human uncoupling protein 3 : protection of mitochondria against accu- mulation of nonesterified fatty acids inside the mitochondrial matrix. Faseb J 2001; 15: 2497-2502

${ }^{36}$ Schrauwen P, Russell AP, Moonen-Kornips E, Boon N, Hesselink MK. Effect of 2 weeks of endurance training on uncoupling protein 3 content in untrained human subjects. Acta Physiol Scand 2005; 183: 273 280

${ }^{37}$ Schrauwen P, Hinderling V, Hesselink MK, Schaart G, Kornips E, Saris $\mathrm{WH}$ et al. Etomoxir-induced increase in UCP3 supports a role of uncoupling protein 3 as a mitochondrial fatty acid anion exporter. Faseb J 2002; 16: 1688 - 1690

38 Russell AP, Schrauwen P, Somm E, Gastaldi G, Hesselink MKC, Schaart $\mathrm{G}$ et al. Decreased fatty acid b-oxidation in riboflavin-responsive multiple acylCoA dehydrogenase deficient patients is associated with an increase in UCP3. J Clin Endocrinol Metab 2003; 88: in press

${ }^{39}$ Himms-Hagen J, Harper ME. Physiological role of UCP3 may be export of fatty acids from mitochondria when fatty acid oxidation predominates: an hypothesis. Exp Biol Med (Maywood) 2001; 226: 78-84

40 Skulachev VP. Anion carriers in fatty acid-mediated physiological uncoupling. J Bioenerg Biomembr 1999; 31: $431-445$

41 de Lange P, Ragni M, Silvestri E, Moreno M, Schiavo L, Lombardi A et al. Combined cDNA array/RT-PCR analysis of gene expression profile in rat gastrocnemius muscle: relation to its adaptive function in energy metabolism during fasting. Faseb J 2004; 18: 350-352

${ }^{42}$ Korshunov SS, Skulachev VP, Starkov AA. High protonic potential actuates a mechanism of production of reactive oxygen species in mitochondria. FEBS Lett 1997; 416: 15 - 18

${ }^{43}$ Hoppeler H, Luthi P, Claassen H, Weibel ER, Howald H. The ultrastructure of the normal human skeletal muscle. A morphometric analysis on untrained men, women and well-trained orienteers. Pflugers Arch 1973; 344: 217-232

${ }^{44}$ Schrauwen P, Hesselink MK. Oxidative capacity, lipotoxicity, and mitochondrial damage in type 2 diabetes. Diabetes 2004; 53: 1412 - 1417

${ }^{45}$ Echtay KS, Esteves TC, Pakay JL, Jekabsons MB, Lambert AJ, PorteroOtin $\mathrm{M}$ et al. A signalling role for 4-hydroxy-2-nonenal in regulation of mitochondrial uncoupling. Embo J 2003; 22: $4103-4110$

${ }^{46}$ Brand MD, Pamplona R, Portero-Otin M, Requena JR, Roebuck SJ, Buckingham JA et al. Oxidative damage and phospholipid fatty acyl composition in skeletal muscle mitochondria from mice underexpressing or overexpressing uncoupling protein 3. Biochem J 2002; 368: 597-603

47 Schrauwen P, Hoeks J, Schaart G, Kornips E, Binas B, Van De Vusse GJ et al. Uncoupling protein 3 as a mitochondrial fatty acid anion exporter. Faseb J 2003; 17: 2272 - 2274

${ }^{48}$ Goglia F, Skulachev VP. A function for novel uncoupling proteins: antioxidant defense of mitochondrial matrix by translocating fatty acid peroxides from the inner to the outer membrane leaflet. Faseb J 2003; 17: 1585-1591

${ }^{49}$ Schrauwen P, Hesselink MK, Blaak EE, Borghouts LB, Schaart G, Saris WH et al. Uncoupling protein 3 content is decreased in skeletal muscle of patients with type 2 diabetes. Diabetes 2001; 50: 2870-2873

${ }^{50}$ Kelley DE, He J, Menshikova EV, Ritov VB. Dysfunction of mitochondria in human skeletal muscle in type 2 diabetes. Diabetes 2002; 51 : $2944-2950$

51 Ritov VB, Menshikova EV, He J, Ferrell RE, Goodpaster BH, Kelley DE. Deficiency of subsarcolemmal mitochondria in obesity and type 2 diabetes. Diabetes 2005; 54: $8-14$

${ }^{52}$ Russell AP, Gastaldi G, Bobbioni-Harsch E, Arboit P, Gobelet C, Deriaz $\mathrm{O}$ et al. Lipid peroxidation in skeletal muscle of obese as compared to endurance-trained humans: a case of good vs. bad lipids? FEBS Lett 2003; 551: $104-106$

${ }^{53}$ Mootha VK, Lindgren CM, Eriksson KF, Subramanian A, Sihag S, Lehar J et al. PGC-1alpha-responsive genes involved in oxidative phosphorylation are coordinately downregulated in human diabetes. Nat Genet 2003; 34: 267-273

54 Patti ME, Butte AJ, Crunkhorn S, Cusi K, Berria R, Kashyap S et al. Coordinated reduction of genes of oxidative metabolism in humans with insulin resistance and diabetes: Potential role of PGC1 and NRF1. Proc Natl Acad Sci U S A 2003; 100: 8466-8471

${ }^{55}$ Brunmair B, Gras F, Wagner L, Artwohl M, Zierhut B, Waldhausl W et al. Expression of uncoupling protein-3 mRNA in rat skeletal muscle is acutely stimulated by thiazolidinediones: an exercise-like effect? Diabetologia 2004; 47: $1611-1614$

${ }^{56}$ Yki-Jarvinen H. Thiazolidinediones. N Engl J Med 2004; 351: $1106-$ 1118 